\title{
Novel Extracellular Chitinases Rapidly and Specifically Induced by General Bacterial Elicitors and Suppressed by Virulent Bacteria as a Marker of Early Basal Resistance in Tobacco
}

\author{
Péter G. Ott, ${ }^{1}$ Gabriella J. Varga, ${ }^{1}$ Ágnes Szatmári, ${ }^{1}$ Zoltán Bozsó, ${ }^{1}$ Éva Klement, ${ }^{2}$ \\ Katalin F. Medzihradszky, ${ }^{2,3}$ Eszter Besenyei, ${ }^{1}$ Arnold Czelleng, ${ }^{1}$ and Zoltán Klement ${ }^{1}$ \\ ${ }^{1}$ Department of Pathophysiology, Plant Protection Institute, Hungarian Academy of Sciences, 1022 Budapest, Pf. 102, \\ Hungary; ${ }^{2}$ Mass Spectrometry Facility, Biological Research Center of the Hungarian Academy of Sciences, 6701 Szeged, \\ Pf. 521, Hungary; ${ }^{3}$ Department of Pharmaceutical Chemistry, School of Pharmacy, University of California San Francisco, \\ San Francisco, CA 94143-0446, U.S.A.
}

Submitted 14 March 05. Accepted 28 September 2005.

\begin{abstract}
Early basal resistance (EBR, formerly known as early induced resistance) is triggered by general bacterial elicitors. EBR has been suggested to inhibit or retard expression of the type III secretion system of pathogenic bacteria and may also prevent nonpathogenic bacteria from colonizing the plant tissue. The quickness of EBR here plays a crucial role, compensating for a low bactericidal efficacy. This inhibitory activity should take place in the cell wall, as bacteria do not enter living plant cells. We found several soluble proteins in the intercellular fluid of tobacco leaf parenchyma that coincided with EBR under different environmental (light and temperature) conditions known to affect EBR. The two most prominent proteins proved to be novel chitinases (EC 3.2.1.14) that were transcriptionally induced before and during EBR development. Their expression in the apoplast was fast and not stress-regulated as opposed to many pathogenesis-related proteins. Nonpathogenic, saprophytic, and avirulent bacteria all induced EBR and the chitinases. Studies using these chitinases as EBR markers revealed that the virulent Pseudomonas syringae pv. tabaci, being sensitive to EBR, must suppress it while suppressing the chitinases. EBR, the chitinases, as well as their suppression are quantitatively related, implying a delicate balance determining the outcome of an infection.
\end{abstract}

Additional keywords: avoidance, innate immunity, PAMP, tolerance, virulence.

Recognition of the broadest possible range of foreign invading organisms and setting up protection measures to anticipate their potentially harmful activity is a prerequisite for successful survival of plants and animals in natural habitats. These basic protective functions are performed by innate immunity mechanisms that share conserved molecular structures in both kingdoms. Accordingly, there are conserved, recognizable molecular fingerprints of pathogens (pathogen associated molecu-

Corresponding author: Peter G. Ott: E-mail: pott@nki.hu

Nucleotide sequence data is available in the GenBank database under accession numbers AJ880384 and AJ880385 for clones CHTO3D9 and CHTO3E10, respectively. lar patterns (PAMPs) or general elicitors) that serve as its elicitors (Nurnberger and Brunner 2002; Schulze-Lefert 2004). Nonpathogens also bear PAMPs, as most known PAMPs are essential components of a bacterial or fungal cell. Thus, probably every microbe bears several PAMPs (Zipfel et al. 2004) whose molecular characterization is crucial to dissect the complex and diverse processes of disease and resistance. A few earlier studies of induced resistance in plants used whole bacterial cells devoid of pathogenic activity (e.g., saprophytes, killed cells, or pathogenicity mutants of pathogens, i.e., collections of PAMPs) or purified cell components as elicitors. There was no pathogenesis or hypersensitive reaction (HR) that would complicate plant responses. Thus, these phenomena represent instances of an ancient form of plant innate immunity, basal resistance, which also has molecular similarities to plant hostspecific pathogen recognition systems (Jones and Takemoto 2004). For example, there were bacterial treatments that interfered with the HR or the normosensitive reaction induced by a subsequent challenge bacterium. These results (Burgyán and Klement 1979; Lovrekovich and Farkas 1965; Lozano and Sequeira 1970) indicated broad induction specificity with an indication of conserved elicitors. Comparable results were obtained with putative bacterial glycoproteins (Sequeira et al. 1972), the lipid A part (Graham et al. 1977), and other domains of lipopolysaccharides (Kecskés et al. 1999; Newman et al. 1997), lipopolysaccharide-protein complexes (Mazzucchi et al. 1979), and bacterial oligosaccharides (Stefani et al. 1994). These and possibly other surface-associated PAMPs like flagellin (Asai et al. 2002) may provide the first opportunity for the plant to mount a sufficiently quick and broadly effective defense against any intruder, not only within a pre-treatment/ challenge artificial inoculation system but also where the naturally infecting bacterial cell itself spurs protective response against itself. We are aware of only one such rapid response described, the early basal resistance (EBR), formerly known as early induced resistance. In tobacco, EBR and late basal resistance (LBR; previous name, late induced resistance) constitute a system that is part of the plant's innate immunity. Several types of bacteria induce protection against the HR-associated death by a subsequent avirulent pathogen or against the normosensitive (susceptible) reaction by a virulent pathogen. The inducer bacteria include live and killed cells of saprophytes and avirulent pathogens, hrp (hypersensitive reaction and patho- 
genicity) mutants of avirulent pathogens and killed cells of the virulent Pseudomonas syringae pv. tabaci. The protection develops within 2 to $6 \mathrm{hpi}$ (hours postinoculation) against HR (Burgyán and Klement 1979) and after about two days against the normosensitive reaction (Lovrekovich and Farkas 1965). The rapid and slower responses are manifestations of EBR and LBR, respectively. Probably because of the presence of one or more conserved and constant bacterial elicitors, EBR is triggered even during an incompatible interaction independently of pretreatment (Burgyán and Klement 1979; Klement et al. 1999, 2003b). The protection against hypersensitive death (by EBR) occurs at a very early stage of the incompatible interaction, i.e., during the 0.5 - to 3-h span of the HR induction period, which is the time needed for bacteria to express and operate their type III secretion system. EBR can be so rapid that the relatively 'slow' $P$. syringae pv. phaseolicola (induction period of HR about $3 \mathrm{~h}$ ) often fails to induce the HR in the absence of pretreatment (Klement et al. 1999). This implies that the bacterium becomes unable to translocate its plant-activated effector proteins into the plant cytoplasm. In agreement with this, blocking EBR with hot-water heat treatment superinduced the expression of most hrp genes of $P$. syringae pv. syringae in planta (Bozsó et al. 1999). Although EBR was found not to be effective against the virulent pathogen $P$. syringae pv. tabaci (Burgyán and Klement 1979), in leaves where EBR is inhibited by heat treatment or by pretreatment with $P$. syringae pv. tabaci, hrp mutant cells of $P$. syringae pv. syringae do not suffer the otherwise normal 90\% drop in their number (Bozsó et al. 1999; Klement et al. 2003b). The mechanism behind the EBR effect is largely unknown. Direct inhibition of challenge bacteria by the inducer bacteria can be excluded in cases where killed bacteria-often of the same strain as the challenge-are used as EBR elicitors. Also, several types of live bacteria, irrespective of their known antibiotic behavior, are successful EBR elicitors. Given the huge surface area of plant cells, spatial exclusion is also improbable. EBR does not prevent cell death provoked by harpin (Klement et al. 1999) or $P$. $s y$ ringae pv. tabaci (Burgyán and Klement 1979). EBR develops sooner at a higher temperature (e.g., 30 vs. $20^{\circ} \mathrm{C}$ ) and in younger leaves. This observation along with the time requirement and sensitivity of EBR to cycloheximide and heat treatment suggests that induced active plant participation is necessary for EBR (Klement et al. 1999, 2003b). All these comply with criteria of induced resistance proposed by Steiner and Schönbeck (1995). EBR may thus affect a broad range of pathogens and nonpathogens, presumably employing extracellular factors such as proteins with rapid expression kinetics, in order to provide an expeditious basic protection mechanism. Our objective was to identify tobacco extracellular proteins that could participate in EBR. A few such proteins were identified as novel chitinases. Their correlation with EBR highlights the specificity and complexity of this immune response.

\section{RESULTS}

\section{EBR induced by one or more general bacterial elicitors correlates with two intercellular washing fluid proteins.}

For preparing the standard bacterial inocula for tobacco (crude preparation of PAMPs), cells of nonhost pathogens $P$. syringae pv. phaseolicola or $P$. syringae pv. syringae were heat-killed $\left(70^{\circ} \mathrm{C}, 12 \mathrm{~min}\right)$, in order to preserve the potential bacterial elicitors while excluding plant-activated bacterial effector activities. In addition, we wanted to ensure that only the plant will be able to produce new proteins. A simplified small-scale method to quickly obtain intercellular washing fluid (IWF) yielded good quality samples; the centrifugal force applied was strong enough to hold the leaf strips in place while mild enough not to cause mechanical damage to the tissue. Using a native 1-D electrophoresis technique with silver staining, it was found that only proteins below approximately $30 \mathrm{kDa}$ distinguished EBR-inducing treatments from the uninoculated (0 hpi) or water-treated control (Fig. 1C). Protein bands of more than $30 \mathrm{kDa}$ were not clearly distinguishable by silver staining because of a high background. Attempts to reduce this background by binding phenolics with PVPP (polyvinyl polypyrrolidone) were not fully satisfactory. Moreover, PVPP partially removed some proteins, which resulted in weaker bands. Six to eight protein bands from the region of tobacco leaf mesophyll cell walls could be reproducibly detected 2 to $12 \mathrm{~h}$ after heat-killed $P$. syringae pv. phaseolicola treatment. Two of these proteins, designated as ' 215 ' and '250,' appeared induced. This period comprises the development ( 2 to $5 \mathrm{hpi}$, depending on the ambient temperature) and maximal expression (approximately 12 to $20 \mathrm{hpi}$ ) of EBR, with heat-killed $P$. syringae pv. phaseolicola as an inducer (Fig. 1A; Klement et al. 2003b). In particular, at $20^{\circ} \mathrm{C}$, the two new IWF proteins appeared later (between 2.5 and $6 \mathrm{hpi}$ ) but persisted longer than at $30^{\circ} \mathrm{C}$. Accordingly, at $30^{\circ} \mathrm{C}$ EBR levels had a shorter but more intense course than at $20^{\circ} \mathrm{C}$. Darkness and old age attenuated the level of the two (and other) proteins. These two effects were additive (Fig. 1A). It has been shown that old leaves develop only weak EBR and that light has an important EBR-maintaining role, especially in older leaves (Klement et al. 2003b). We observed that EBR persists for about one week in the dark, albeit its strength diminished after 1 to 2 days (Fig. 1A). The two bands disappeared from leaf samples during this week whether in light or not (Fig. 1A). Several additional controls were included to warrant proper selection of EBR-related IWF proteins. No more additional protein bands were detected when IWF was concentrated about 10 times with ultrafiltration (not shown). Thus, silver-staining was sensitive enough to detect all proteins in IWF that is dilute with respect to proteins (approximately 5 to $20 \mu \mathrm{g} \mathrm{ml}^{-1}$ ), while other staining methods (Coomassie brilliant blue, fluorescent staining) usually fell short of detecting the less abundant proteins, e.g., 215 and 250. There was a negligible change in the protein pattern upon using protease inhibitor cocktails. The quantity of two very small proteins decreased, indicating activity of extracellular proteases. No changes were observed for any of the induced proteins (not shown). There were no proteins in the bacterial inocula with a migration distance similar to the two induced bands (Fig. 1C). When IWF from noninoculated leaves was mixed with heatkilled $P$. syringae pv. phaseolicola inoculum in a test tube or when IWF was taken out of heat-killed $P$. syringae pv. phaseolicola-inoculated leaves before expression of the induced proteins and was incubated in vitro at $24^{\circ} \mathrm{C}$, none of these protein bands were detected as compared with the starting material (Fig. 1C). This indicates that induction of the new proteins by heat-killed $P$. syringae pv. phaseolicola requires an active plant response. Appearance of the two new bands was not due to the cutting of the leaves (not shown). Because of general differences between individual gels, the absolute band densities varied considerably. The percentages of the individual proteins within total band densities in gels were much more consistent. Figure $1 \mathrm{~B}$ shows the ratio of the two proteins in the protein mixture after combinations of bacterial and heat treatments. A short but intense heat treatment $\left(51^{\circ} \mathrm{C}, 15 \mathrm{~s}\right)$ just before inoculation with heat-killed $P$. syringae pv. phaseolicola delayed the EBR effect by 12 to 16 h, so EBR recovered by 24 hpi (not shown). Also, the two bands did not appear or appeared only very weakly during this time. However, the proteins appeared by 24 hpi (Fig. 1B). This reinforces that EBR inhibition by heat treatment is the result of blocking either the protein synthesis, transport, or both, as such processes were reported to be 
A
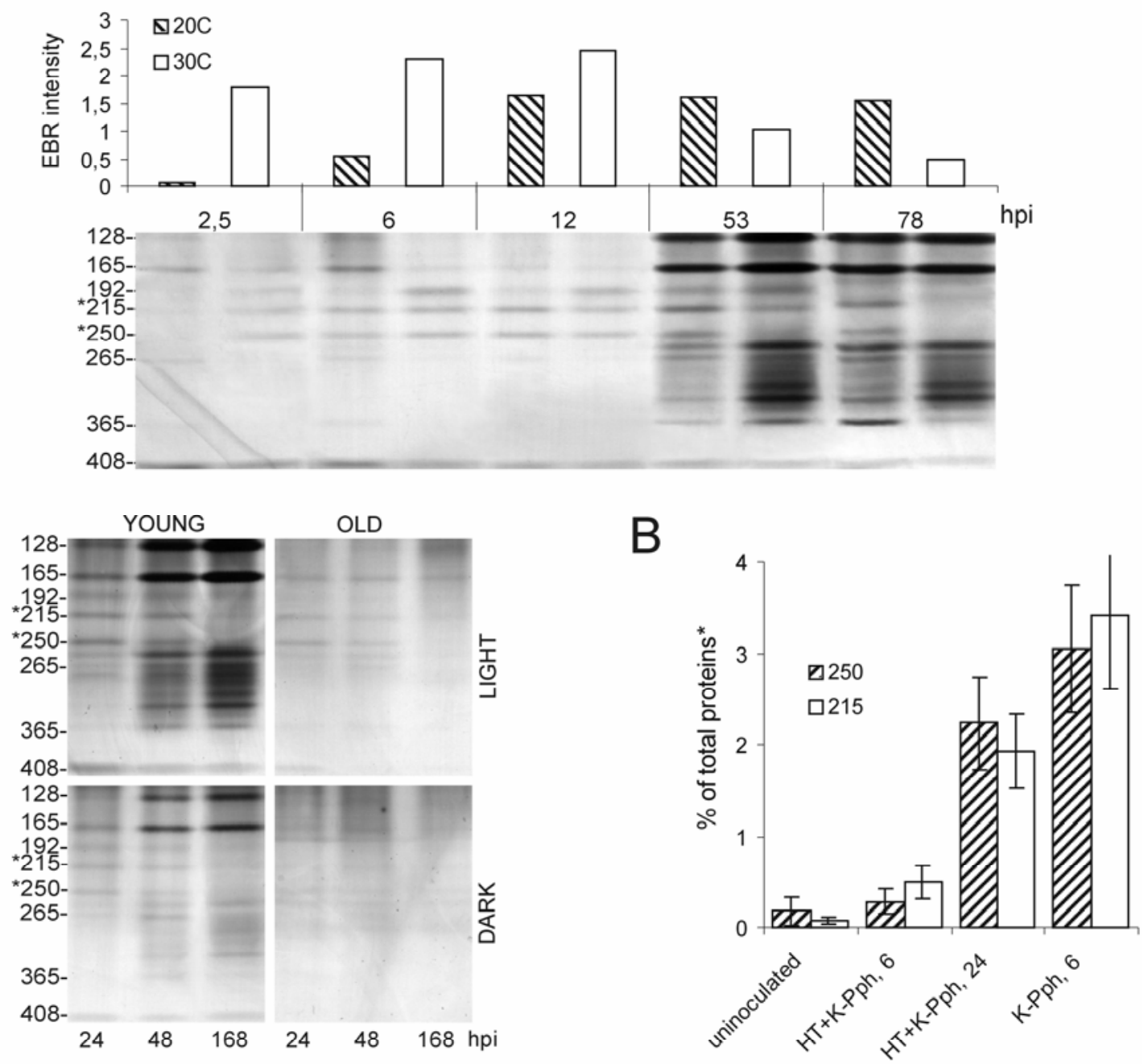

C

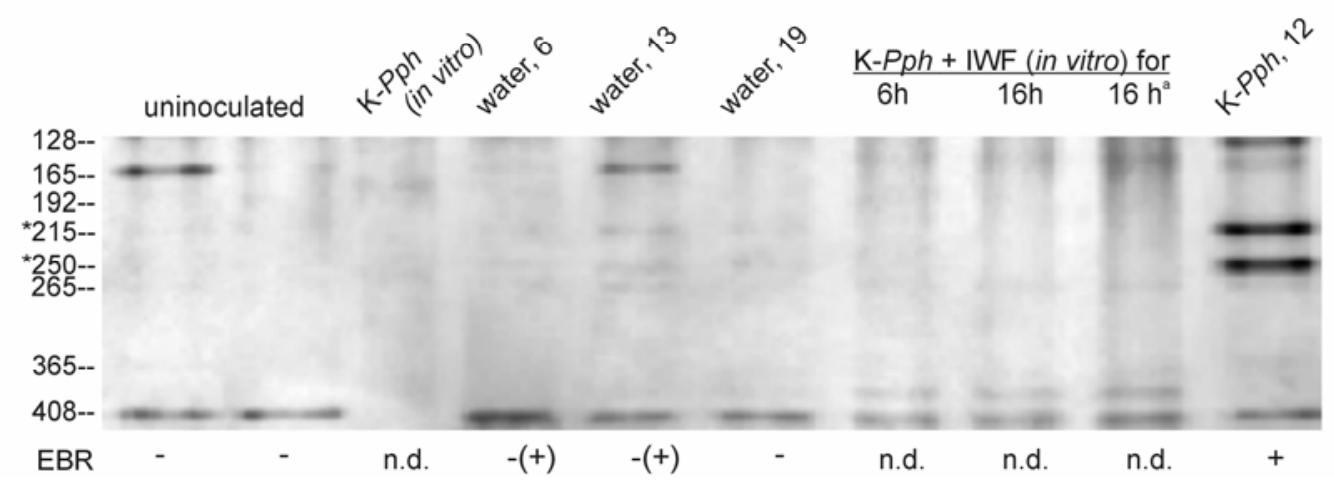

Fig. 1. Correlation of two IWF (intercellular washing fluid) proteins (asterisks) and early basal resistance (EBR), induced by heat-killed bacteria. Experiments were carried out at least three times with similar results. A, Timecourse of EBR and IWF protein patterns in leaves treated with heat-killed Pseudomonas syringae pv. syringae. The bar chart shows intensity of EBR in midposition leaves. A standardized scale from 1 (approximately $50 \%$ hypersensitive reaction [HR]) to $3(0 \%$ or HR fully inhibited) was used. Average values of nine experiments are shown. The gel below the chart shows early timepoints with lanes corresponding to the chart columns. The bottom gel shows the influence of leaf age and illumination on the protein patterns on a longer time scale. Numbers on the left of the gels are proportional to the relative mobility of the proteins and are used as reference for the respective bands. Only the lower half of the gels are shown, with proteins below approximately $30 \mathrm{kDa}$. B, Band densities of two candidate EBR-related proteins. Two proteins ('215' and '250') are shown that coincided with EBR (A and C) and proved consistent through several plant sets. HT = heat-treatment of leaves; K-Pph = infiltrated with heatkilled $P$. syringae pv. phaseolicola $;+=$ treatments together; numbers after treatments indicate hours after inoculation (hpi); * $=$ except basic proteins. Error bars $=$ standard error of the mean, $n=3 . \mathbf{C}$, Protein pattern of control treatments. Uninoculated $=$ variations of IWF samples from untreated leaves; K-Pph $=$ heat-killed $P$. syringae pv. phaseolicola inoculum; in vitro = not in planta study; numbers after treatments indicate hpi; K-Pph $+\mathrm{IWF}=\mathrm{bacterial}$ cells were mixed with IWF from untreated leaves in a test tube and were incubated at $22^{\circ} \mathrm{C}$ for the time indicated. Only bands smaller than $30 \mathrm{kDa}$ are shown. The superscript a indicates two times more sample was loaded. Below the lanes, $(+)$ or $(-)$ signs indicate whether EBR was operative or not, respectively, as evidenced by the HR test; -(+) indicates weak and less durable EBR in a minority of cases, and n.d. indicates not determined. 
blocked by severe heat shock (Welch and Suhan 1985; Yost and Lindquist 1986). The identical delay in the EBR effect and in the proteins' appearance further strengthens their relationship.
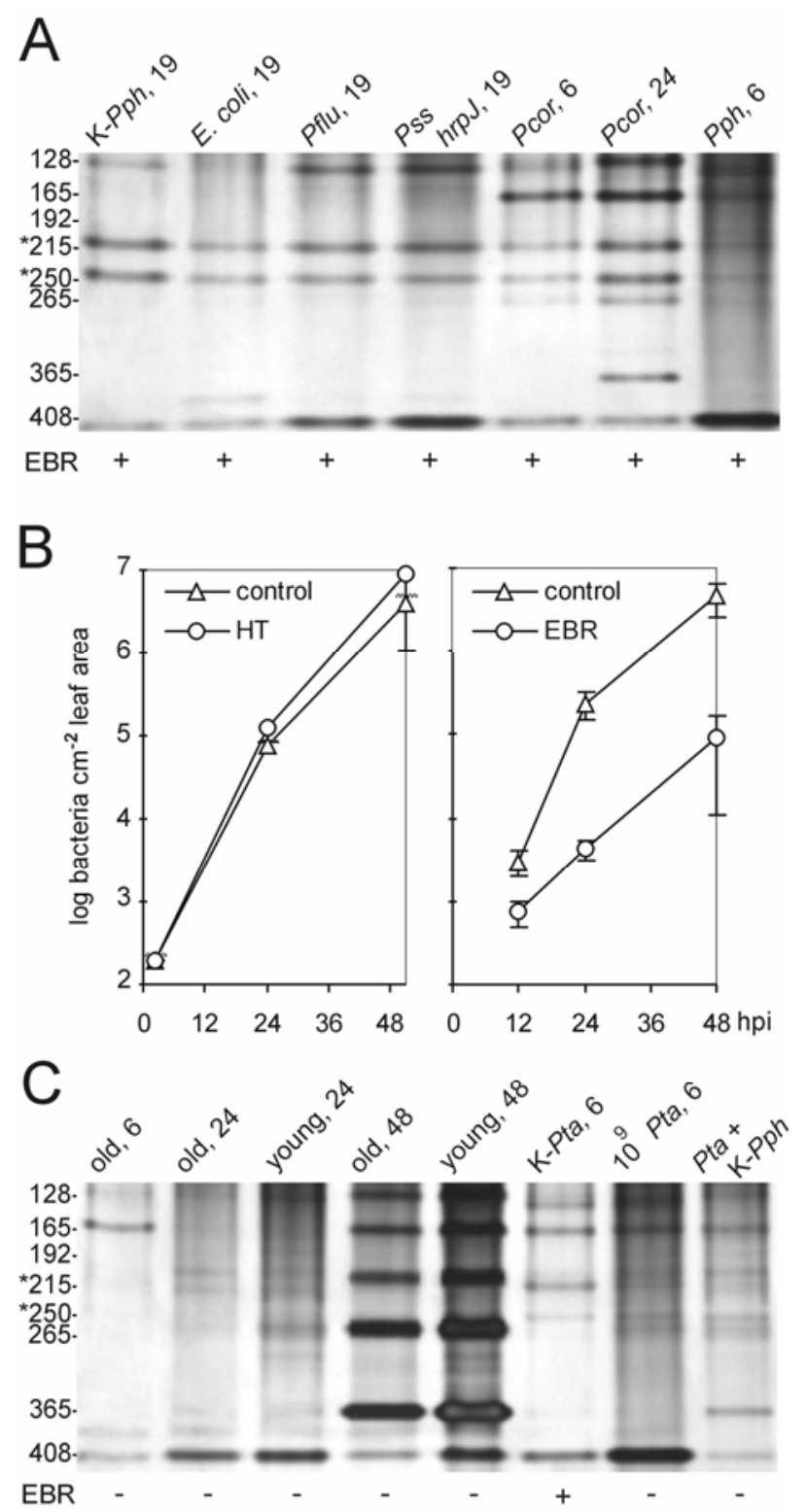

Fig. 2. IWF (intercellular washing fluid) protein patterns from leaves inoculated with live bacteria. Only bands smaller than $30 \mathrm{kDa}$ are shown from the gels. Experiments were carried out at least three times with similar results. Below the lanes, (+) or (-) signs indicate whether EBR (early basal resistance) was operative or not, respectively, as evidenced by the hypersensitive reaction test. $\mathrm{K}-=$ heat-killed (included for reference); numbers after treatments indicate hours after inoculation. A, IWF protein pattern of leaves treated with $5 \times 10^{8} \mathrm{CFU}$ of nonvirulent bacteria per milliliter. Pph $=$ Pseudomonas syringae pv. phaseolicola $;$ E. coli $=E s$ cherichia coli; $P$. flu $=$ P. fluorescens; Pss hrpJ $=$ hrpJ mutant of $P$. syringae pv. syringae; Pcor $=P$. syringae pv. coriandricola . B, Growth of $P$. syringae pv. tabaci in tobacco leaves, starting from an inoculum density of $10^{5} \mathrm{CFU} \mathrm{ml}{ }^{-1}$. Left chart, effect of heat-treatment (HT); right chart, effect of $6 \mathrm{~h}$ pretreatment with $5 \times 10^{8}$ cells $\mathrm{ml}^{-1}$ heat-killed $P$. syringae pv. phaseolicola (EBR). Error bars indicate $2 \times$ standard error of the mean. In the left chart, only the lower error bars are shown for the HT and the upper ones for the control. C, IWF protein patterns of tobacco leaves of different ages after infiltration with $P$. syringae pv. tabaci $\left(\right.$ Pta, $2 \times 10^{5} \mathrm{CFU}$ per milliliter unless stated otherwise); old = older leaf; young = younger leaf; $10^{9}=$ high-density $\left(10^{9} \mathrm{CFU} \mathrm{ml}{ }^{-1}\right)$ inoculum; Pta $+\mathrm{K}-P$ ph $=P$. syringae $\mathrm{pv}$. tabaci infection for $24 \mathrm{~h}$, challenged with heat-killed $P$. syringae pv. phaseolicola $\left(5 \times 10^{8}\right.$ cells per milliliter $)$ and sampled at $6 \mathrm{~h}$ thereafter.
Pathogenic bacteria are sensitive to EBR, but only the virulent $P$. syringae pv. tabaci suppresses it and the expression of the two proteins in the cell wall.

The next question was how specific was the induction of the two proteins by living bacteria that represent different types of interactions with tobacco. Non-plant pathogenic bacteria (Escherichia coli), the saprophytic or hrp mutants ( $h r p J$ is shown here) of $P$. syringae pv. syringae, triggered the appearance of the 215 and 250 bands within 6 hpi. Treatment with live avirulent bacteria ( $P$. syringae pv. phaseolicola, $P$. syringae pv. syringae, $P$. syringae pv. coriandricola) also resulted in the appearance of the representative bands, and the HR also occurred here later.

Apart from some small ( $<5 \mathrm{kDa}$; not shown) polypeptides, the polyacrylamide gel electrophoresis (PAGE) separation pattern was similar to that induced by heat-killed $P$. syringae pv. phaseolicola (Fig. 2A). The above experiments with nonvirulent bacteria indicate that two relatively small proteins could be part of the EBR.

As for the compatible interaction, the most important type, we found that leaf tissue hosting a rapidly multiplying high $P$. syringae pv. tabaci population did not express or only weakly expressed the two proteins (Fig. 2C). In the late samples (from 30 hpi on), bacterial number reached or exceeded the amount used for routine EBR induction $\left(5 \times 10^{5}\right.$ to $5 \times 10^{7}$ cells cm $\mathrm{cm}^{-2}$ of leaf area) (Fig. 2B, control growth curves). On the other hand, heat-killed $P$. syringae pv. tabaci induced the 215 and 250 proteins (Fig. 2C). To deactivate $P$. syringae pv. tabaci cells and otherwise preserve their elicitor quality, we tried gamma radiation on cells frozen in liquid nitrogen. A 3.2-kGy dose sufficiently killed the bacteria but did not produce any differences between elicitor activities of the heat-killed and gamma ray-killed cells. Live $P$. syringae pv. tabaci moderately induced the proteins if inoculated at an unnaturally high $\left(10^{9}\right.$ CFU ml ${ }^{-1}$ ) cell density at 6 hpi (Fig. 2B).

The above results with $P$. syringae pv. tabaci show that, in spite of bearing the elicitors of the proteins 215 and ' 250 ,' the virulent bacterium has the ability to keep their expression at a low level. This suggested that EBR may have significance during infection that has been underestimated so far. Therefore, we examined possible pathogenic strategies of $P$. syringae pv. tabaci, such as avoidance, tolerance, and suppression, with respect to the EBR, to assess its significance in the pathogenesis. The fact that this bacterium multiplies rapidly and causes necrotic symptoms fits to all or any one of the three strategies. Killed $P$. syringae pv. tabaci induced EBR, such as cells of several other bacteria (Burgyán and Klement 1979; Table 1, sequence C). EBR (induced by heat-killed $P$. syringae pv. pisi) did not inhibit the normosensitive necrosis by a high dose of $P$. syringae pv. tabaci (above $10^{6} \mathrm{CFU} \mathrm{ml}^{-1}$; Table 1 , sequence $\mathrm{D}$ ) but greatly retarded infection by a lower-dose inoculum $\left(10^{5}\right.$ CFU ml ${ }^{-1}$; Table 1 , sequence E). This delay lasted up to 2 weeks, whereas plants treated with only $P$. syringae pv. tabaci developed necrotic symptoms after 4 to 5 days. The delay was also reflected by a lower multiplication rate (Fig. 2B, growth curve EBR). When a tissue pretreated with rifampin-sensitive $P$. syringae pv. tabaci is challenged with a rifampin-resistant avirulent bacterium, e.g., $P$. syringae pv. pisi along with rifampin, HR appears in the outer zone, which has been interpreted as lack of EBR in the tissue infected with $P$. syringae pv. tabaci (Klement et al. 2003b, Table 1, sequence F). When this series of treatments was done after an EBR-inducing treatment, there was no HR (Table 1, sequence I). When heat-killed P. syringae pv. tabaci $\left(5 \times 10^{8}\right.$ cells $\left.\mathrm{ml}^{-1}\right)$ was mixed with a lower number of live $P$. syringae pv. tabaci cells $\left(2 \times 10^{5}\right.$ cells $\mathrm{ml}^{-1}$ or less), it also greatly delayed, if not prevented, the compatible symptoms (Table 1, sequence A). Lastly, pretreatment 
with only active $P$. syringae pv. tabaci inhibited EBR (Table 1, sequences $\mathrm{G}$ and $\mathrm{H}$ ) as assessed by the HR test (Table 1, sequence B), and again, this activity of the virulent bacterium could be disturbed by pretreatment with heat-killed bacterial cells (Table 1, sequence J).

Taken together, elicitor activity of a cell constituent can delay or impair disease by overwhelming another activity of live $P$. syringae pv. tabaci cells that, under normal progression of disease, actually suppresses EBR and the expression and secretion of 215 and 250 proteins.

\section{Abiotic stresses or defense signaling compounds (salicylic acid, jasmonic acid, and ethylene) are poor inducers of proteins 215 and 250'.}

Salt stress $(0.2 \mathrm{M} \mathrm{NaCl})$, osmotic stress ( $0.4 \mathrm{M}$ mannitol) induced to a low level (Fig. 3A), $300 \mathrm{mM} \mathrm{H}_{2} \mathrm{O}_{2}$, and $20 \mu \mathrm{M}$ paraquat, a generator of intracellular superoxide, did not induce appearance of the two proteins in the IWF (Fig. 3B). Notably, in some instances, even water proved a weak elicitor (Fig. 1C), approximately at the level of $\mathrm{NaCl}$ or mannitol (not shown). In these cases, water also resulted in an EBR-like effect, but this kind of protection against $\mathrm{HR}$ induction lasted only for a few (below 20) hours. At $0.5 \mathrm{M}, \mathrm{NaCl}$ caused necrotic symptoms to a greater extent in older leaves than in younger ones. Mannitol treatment was symptomless. Leaf infiltration with $300 \mathrm{mM} \mathrm{H}_{2} \mathrm{O}_{2}$ did not cause necrotic symptoms. Younger leaves tolerated even $1 \mathrm{M} \mathrm{H}_{2} \mathrm{O}_{2}$. At higher concentrations, yellowish discoloration and spotty death occurred, especially close to the injection point. In older leaves, 40 to $50 \mu \mathrm{M}$ paraquat caused necrotic spots at the injection point that could spread beyond the initial infiltration area, mainly along major leaf veins.

Salicylic acid (SA), jasmonic acid (JA), and ethylene pathways are often involved in stress- and defense responses to pathogens, often along with the accumulation of these compounds. Ethylene (1-aminocyclopropane-1-carboxylic acid at 1 $\mathrm{mM})$, JA $(100 \mu \mathrm{M})$, or SA $(0.6 \mathrm{mM})$ did not induce or only poorly induced the expression of the two proteins or EBR at 6 hpi or later (Fig. 3C). However, we observed protection from
HR by JA between 24 and 96 hpi that was pronounced only in older leaves. Here, JA treatment acted on the death process by slowing it considerably. SA treatment resulted in only a short period (approximately 4 to $10 \mathrm{hpi}$ ) of an EBR-like effect. Moreover, EBR developed in NahG plants that do not accumulate SA (data not shown).

In summary, based on their coincidence with EBR under a variety of conditions, at least two proteins of less than $30 \mathrm{kDa}$ proved to be good candidates for EBR-related proteins. The corresponding proteins, detectable only with silver-staining in the unconcentrated IWF, were shown to correlate with EBR development qualitatively and semiquantitatively.

\section{The two proteins are novel chitinases (EC 3.2.1.14) with early transcriptional control.}

Tryptic digests of the two PAGE-purified proteins were analyzed unfractionated by matrix-assisted laser desorption-ionization time of flight mass spectrometry (MALDI-TOF MS). Each digest yielded more than 20 peptides, approximately $80 \%$ of which were present in both samples (data not shown). Thus, we concluded that the proteins were related. Database search with the singly charged protonated peptide masses $\left(\mathrm{MH}^{+}\right)$detected in the tryptic digest did not identify any protein. Then PSD (post source decay) experiments were performed on the six most abundant components present: $\mathrm{MH}^{+}$at $\mathrm{m} / \mathrm{z} 779.43$, 1,588.76, 1,748.84, 1,899.96, 2,464.2, and 2,649.2 (data not shown). Two PSD spectra, those of $\mathrm{m} / \mathrm{z} 779.43$ and $1,588.76$ were manually interpreted and yielded amino acid sequences DAVI/LSFK and PDI/LVAR, respectively. (Isomeric ile and leu residues cannot be differentiated by PSD analysis.) These sequences showed similarity (MS pattern search with Protein Prospector software; Clauser et al. 1999) to a 26-kDa chitinase isolated from Jack bean (National Center for Biotechnology Information [NCBI] number 10120702), corresponding to positions 144 to 150 and 138 to 143 , respectively. Interestingly, a MS-TAG database search (Protein Prospector software; Clauser et al. 1999) with the PSD data of $\mathrm{m} / \mathrm{z} 1,748.84$ 'identified' a tryptic peptide, GPLQISWNFNYGPAGK, from a $25-\mathrm{kDa}$ rice chitinase (NCBI number 7435372). The identity of the under-

Table 1. Phenotypic outcomes of bacterial treatments with mixed or sequential inocula

\begin{tabular}{|c|c|c|c|c|c|}
\hline Sequence & First inoculation $^{\mathrm{a}}$ & Time gap ${ }^{b}$ & Challenge inoculation(s) ${ }^{\mathrm{c}}$ & HR $(N N)^{d}$ & Notes $^{\mathrm{e}}$ \\
\hline$\overline{\mathrm{A}}$ & $\begin{array}{l}\text { Heat-killed cells }\left(5 \times 10^{8}\right) \text { mixed } \\
\text { with live } P . \text { syringae pv. tabaci } \\
\left(2 \times 10^{5} \text { or less }\right)\end{array}$ & & & $(-) ;( \pm)$ & Tissue death is delayed or even prevented \\
\hline B & Heat-killed avirulent $5 \times 10^{7}$ & 7 to 18 & Avirulent & - & Establishment of EBR, test for EBR \\
\hline $\mathrm{C}$ & $\begin{array}{l}\text { Heat-killed } P \text {. syringae pv. } \\
\text { tabaci } 2 \times 10^{8}\end{array}$ & 6 & Avirulent & - & $\begin{array}{l}\text { Cellular constituent(s) of } P \text {. syringae pv. tabaci } \\
\text { induce the EBR }\end{array}$ \\
\hline $\mathrm{D}$ & Heat-killed avirulent $5 \times 10^{8}$ & 7 & P. syringae pv. tabaci $10^{7}$ to $10^{9}$ & $(+)$ & EBR does not inhibit NN \\
\hline $\mathrm{E}$ & Heat-killed avi & 7 & $\begin{array}{l}P . \text { syringae pv. tabaci } 5 \times 10^{5} \\
\text { and below }\end{array}$ & $(-)$ & $\begin{array}{l}\text { EBR delays pathogenesis by } P \text {. syringae pv. } \\
\text { tabaci }\end{array}$ \\
\hline $\mathrm{F}$ & P. syringae pv. tabaci $5 \times 10^{7}$ & 7 & Avirulent & + & $\begin{array}{l}\text { Live } P \text {. syringae pv. tabaci pretreatment does } \\
\text { not result in EBR }\end{array}$ \\
\hline G & P. syringae pv. tabaci $10^{6}$ & 24 & 'B' & + & $\begin{array}{l}\text { P. syringae pv. tabaci can inhibit development } \\
\text { of the EBR }\end{array}$ \\
\hline $\mathrm{H}$ & $\begin{array}{l}\text { Heat-killed P. syringae pv. } \\
\text { tabaci } 10^{6}\end{array}$ & 24 & 'B' & - & $\begin{array}{l}\text { Result of 'G' is dependent on metabolic activity } \\
\text { of } P \text {. syringae pv. tabaci }\end{array}$ \\
\hline I & Heat-killed avirulent $5 \times 10^{8}$ & 16 & 'F' & - & $\begin{array}{l}\text { P. syringae pv. tabaci infection does not } \\
\text { abolish established EBR }\end{array}$ \\
\hline $\mathrm{J}$ & Heat-killed avirulent $5 \times 10^{8}$ & 6 & 'G' & - & $\begin{array}{l}\text { EBR inhibits EBR-inhibitory activity of } P \text {. } \\
\text { syringae pv. tabaci }\end{array}$ \\
\hline \multicolumn{6}{|c|}{$\begin{array}{l}\text { a Heat-killed bacteria, avirulent (Pseudomonas syringae pv. pisi, } P \text {. syringae pv. phaseolicola, P. syringae pv. syringae), and virulent (P. syringae pv. tabaci) } \\
\text { bacteria themselves cause symptomless responses, hypersensitive reaction (HR), and normosensitive necrosis (NN), respectively. Numbers indicate cell } \\
\text { density, cells } \mathrm{ml}^{-1} \text {. } \\
{ }^{\mathrm{b}} \text { Hours between the first and the following inoculation (or inoculation series). } \\
{ }^{\mathrm{c}} \text { Single capital letters in quotes indicate inoculation sequences indentified in the first column. } \\
\mathrm{d}^{\mathrm{d}}+=\text { tissue death; }-=\text { no tissue death; } \pm=\text { variable with high challenge inoculum. NN is shown in parentheses. Distinction between HR and NN was } \\
\text { possible in ' } F \text { ' and 'G' using parallel controls, checking times for death development and symptoms. } \\
\text { e EBR = early basal resistance. }\end{array}$} \\
\hline
\end{tabular}


lined amino acids was confirmed by $\mathrm{N}$-terminal and $\mathrm{C}$-terminal fragment ions (data not shown). These data suggest the presence of a novel chitinase in tobacco plants.

Using in-gel chitinase activity analysis, the earliest and the most consistent activities could be coupled to the two abovecharacterized proteins, 215 and 250 (Fig. 4). Importantly, the electrophoretic band densities of the silver-stained chitinases were proportional to their in-gel enzymatic activities. An additional chitinase activity was also obvious for a larger protein (Fig. 4, at or close to band 128) that is also inducible by heatkilled bacteria. This chitinase activity was also suppressed by P. syringae pv. tabaci infection (Fig. 4). There is a constitutive chitinase activity as well, provided by an even larger protein. This activity was less subject to changes in the course of treatments and was the only one found in uninoculated leaves. The
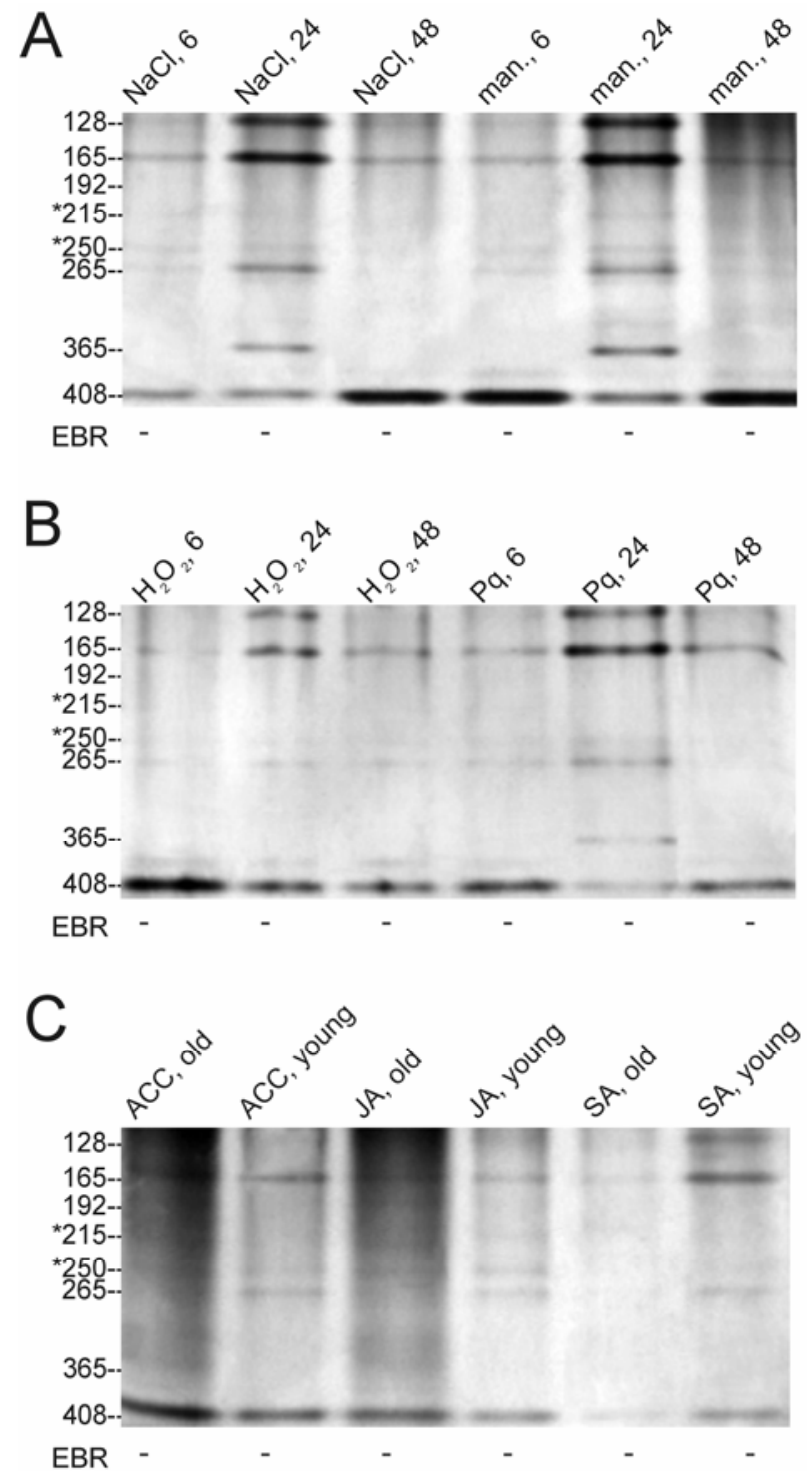

Fig. 3. Stress-related expression of IWF (intercellular washing fluid) proteins. Only bands smaller than $30 \mathrm{kDa}$ are shown. Below the lanes, $(+)$ or (-) signs indicate whether EBR (early basal resistance) was operative or not, respectively, as evidenced by the hypersensitive reaction test. Numbers after treatments indicate hours after inoculation (hpi). A, Salt and osmotic stresses. $\mathrm{NaCl}$ and mannitol (man.) were used at $0.1 \mathrm{M}$. B, Oxidative stresses. $\mathrm{H}_{2} \mathrm{O}_{2}$ was used at $0.3 \mathrm{M}$, paraquat $(\mathrm{Pq})$ at $20 \mu \mathrm{M}$. C, Stress- and defense-related plant compounds. 1-Aminocyclopropane-1carboxylic acid (ACC) and jasmonic acid (JA) were used at $1 \mathrm{mM}$ and salycylic acid (SA) at $0.6 \mathrm{mM}$ in older and younger leaves at $19 \mathrm{hpi}$. Experiments were carried out at least three times with similar results. size of chitinases 215 and 250 is estimated at approximately $15 \mathrm{kDa}$, as judged from ultrafiltration studies and running size standards (not shown).

To determine whether the chitinases are subject to transcriptional control related to EBR, cDNA samples were prepared from tobacco leaves treated with a $P$. syringae pv. syringae hrp mutant ( $h r c C$ mutant, a known inducer of EBR) in a timecourse of 1 to 48 hpi. Redundant gene-specific PCR primer was designed on the conserved region of the chitinase peptides, with the help of known tobacco and Arabidopsis chitinase sequences. Polymerase chain reaction (PCR) yielded four visible products, three of which were cloned. Nucleotide sequences were obtained and interpreted using the BLAST program (Altschul et. al. 1990).

Two of the obtained sequences were novel, with relatively low similarities to any known gene. Highest identities were to CHTO3D9, a Sambucus nigra chitinase class II (PR-3), GenBank accession number Z46950, 73\%, and CHTO3E10, Oryza sativa, GenBank accession number XM_483800, 75\%. The third sequence, CHTO1A2, corresponded (99\% identity) to a known gene, the N. tabacum endochitinase, GenBank accession number X16939.

MS and PSD analysis of the tryptic digests of gel bands 215 and 250 suggest that both may be the products of gene CHTO3D9 (Fig. 5A). The two protein digests were almost identical $(80 \%)$, and the amino acid sequence deduced from PCR product CHTO3D9 matched components identified from both digests. Since the sequences underlined seem to be identical in both proteins, we assume that the missing $\mathrm{N}$-terminal region must be different, possibly due to heterogeneity in the still unknown N-terminal part, posttranslational modifications, or both. Inverse PCR deciphering the N-terminal sequence is underway.

Expression levels of the corresponding genes were assessed by real time reverse transcription (RT)-PCR in a timecourse, using specific primers for the above three sequences. Expression patterns obtained this way corresponded well to the original 3'Race PCR (not shown) and the electrophoretic data as well. CHTO3D9 was strongly and selectively induced in bacterially treated cDNA samples, such as chitinases 215 and 250. Gene activity was already high at $1 \mathrm{hpi}$ and declined after $12 \mathrm{hpi}$ (Fig. 5B). CHTO1A2 was constitutive. CHTO3E10 was strongly induced in water- and bacteria-treated samples at 1 hpi and was already low at $3 \mathrm{hpi}$ (data not shown).

Thus, CHTO3D9 corresponds to either chitinase '215,' '250,' or both, the extracellular accumulation of which may be transcriptionally regulated.

\section{DISCUSSION}

Our objective was to find EBR-related proteins in the IWF, in which plant effector proteins are likely to be found with roles in a putative initial recognizing function, the final bacteriostatic function, or both. Selection criteria were early induction and a good correlation between proteins and EBR under experimental conditions known to arouse, stimulate, or inhibit this form of innate immunity. The two most relevant proteins proved to be novel soluble extracellular chitinases, a fact that implies several possibilities for their function in a broadly effective resistance response. EBR, possibly with the related chitinases, is a factor to combat with for any bacterium that contacts the leaf parenchyma, including the most specialized virulent pathogen.

\section{Specificity of EBR-related chitinase induction.}

Having used a variety of bacterial elicitors, controls, environmental conditions and stresses, as well as leaves of different ages, we conclude that these chitinases are specific for the 
EBR machinery. First, several bacterial cell types not having a functional type III secretion system (saprophytic bacteria, heat-killed avirulent, virulent, or live hrp mutant bacteria) known to trigger EBR also induced the chitinases before or within the EBR time frame. There is probably a common, general elicitor of EBR as well as these proteins, most likely on the bacterial cell surface, as the surface is exposed towards the plant cell and killed cells also are active elicitors. Experiments are now conducted to test known PAMPs such as flagellin (Felix et al. 1999), cold shock protein (Felix and Boller 2003), and lipopolysaccharide preparations (Kecskés et al. 1999). The broad induction specificity suggests effectivity against a broad range of bacteria. EBR might lead to an answer to the old and neglected question why saprophytes cannot grow in living tissue in spite of having all the necessary nutrients (Klement et al. 1964). Second, conditions and treatments manipulating EBR similarly affected the presence of the chitinases. These conditions include inhibition by (Visnyovszky et al. 1983) and recovery from heat treatment, acceleration at higher $\left(30^{\circ} \mathrm{C}\right)$ as compared with lower $\left(20^{\circ} \mathrm{C}\right)$ temperatures, and persistence and reinforcement by light and juvenility (Klement et al. 1999, $2003 \mathrm{~b}$ ). Moreover, quantity of the chitinases seemed to be proportionally related to the strength of EBR, when the latter was not artificially blocked by heat treatment or provoked by challenge. Nevertheless, as EBR was never observed in the absence of these proteins, they might be components of the EBR machinery. Third, abiotic stresses such as salt and osmotic stresses did not trigger, or only very poorly triggered, appearance of neither the chitinases nor the EBR itself. Chitinases and EBR coincided also at these low levels, as exemplified in some water-treated control samples (Fig. 1C). The broad-range bacterial induction suggested a possible incorporation of abiotic stress responses into the EBR signal pathway. This possibility now seems unlikely. Many pathogenesis-related proteins are induced by abiotic stresses and rather late (Ohashi and Ohshima 1992). In contrast, the EBR-related chitinases seem to discriminate between abiotic and biotic stress stimuli. Biotic and abiotic stresses are generally associated with elevated production of reactive oxygen species extracellularly and intracellularly, respectively (Mittler 2002). We found relatively low and transient $\mathrm{H}_{2} \mathrm{O}_{2}$ accumulation during the development of EBR as compared with the HR (Klement et al. 2003b). However, neither $\mathrm{H}_{2} \mathrm{O}_{2}$ nor superoxide induced the chitinases or EBR, indicating that reactive oxygen species elevation is rather a consequence or, at least, not the single cause of EBR development. Fourth, application of defense-related plant compounds, such as ethylene or SA, did not result in an EBR-like effect or resulted in a very short-living one. The chitinases were expressed accordingly. Independence of EBR from SA is apparent from the fact that EBR was observed in NahG plants. Longer SA pretreatment seemed even to potentiate the HR in the leaves, a fact that was previously known (Alvarez 2000). JA treatment, such as heat-killed bacterium pretreatment, delayed HR by a challenge bacterium, but JA is an unlikely substitute for heat-killed bacteria because EBR (induced by heat-killed bacteria) inhibits rather than slows down the HR and takes effect significantly earlier than the protection caused by JA. This indicates that JA acts on the plant-dictated part of the HR, i.e., the latent or death period. JA, antagonizing SA, was shown to abolish cell death induced by $\mathrm{O}_{3}$ (Rao et al. 2000) or by harpin (Andi et al. 2001). Also, EBR is more functional in younger leaves than in older ones, as opposed to JA. Further studies are necessary to decide whether the ethylene or JA pathways, which often interact with each other and with the SA pathway (Kunkel and Brooks 2002), are required for EBR.

\section{EBR-related chitinases and EBR after infection with plant pathogenic avirulent and virulent bacteria.}

Recognition of PAMPs is considered as the evolutionary predecessor of avirulence factor recognition (Klement et al. 2003a; Navarro et al. 2004; Nurnberger and Brunner 2002). This reflects a temporally defined relationship of EBR and HR during defense. The PAMPs are available for perception by the plant from the very beginning of the bacterium-plant interaction, well before the bacteria are supposed to translocate their effector proteins into the plant cell. Thus, EBR signaling commences whether or not the bacteria perform translocation, in which case, EBR buildup runs parallel with that of the translocation machinery. When translocation succeeds, EBR may have failed to inhibit bacteria during their HR-induction period (Klement et al. 1999). Such stepwise progress of inducible defense was put forward in the $P$. syringae pv. phaseolicolaArabidopsis nonhost interaction (Tao et al. 2003), which does not result in HR (Lu et al. 2001) and thus appears similar to the $P$. syringae pv. phaseolicola-tobacco interaction at $30^{\circ} \mathrm{C}$.

The EBR-related chitinases are expressed during the HR, so it is plausible to assume that the bacteriostatic effect of EBR constitutes part of the strong successive resistance provided by

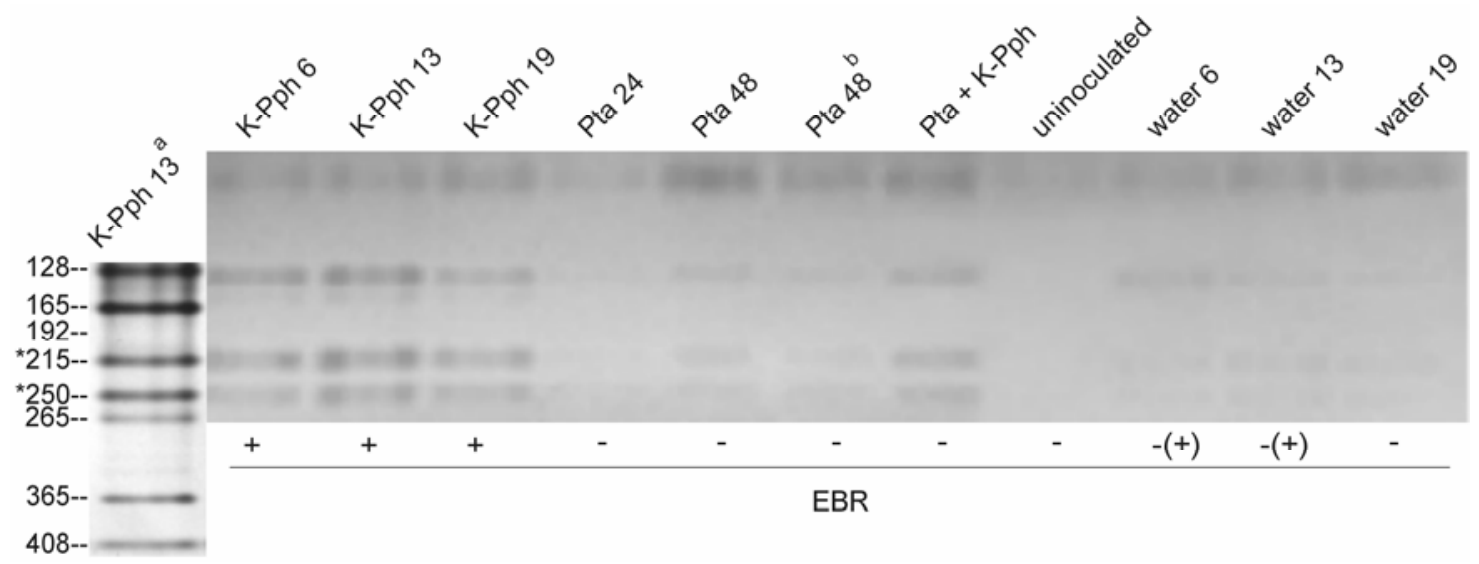

Fig. 4. In-gel chitinase activity of IWF (intercellular washing fluid). K-Pph = heat-killed P. syringae pv. phaseolicola; Pta $=$ P. syringae pv. tabaci; Pta+K$P$ ph $=$ P. syringae pv. tabaci $\left(2 \times 10^{5} \mathrm{CFU} \mathrm{m}^{-1}\right)$ infection for $24 \mathrm{~h}$, challenged with $5 \times 10^{8}$ cells of heat-killed $P$. syringae pv. phaseolicola per milliliter and sampled at $6 \mathrm{~h}$ thereafter; numbers after treatments indicate hours after inoculation; the superscript a indicates an aligned piece of a silver-stained gel; the lane indicated by the superscript b was included to show pattern variation; below the lanes, (+) or (-) signs indicate whether EBR (early basal resistance) was operative or not, respectively, as evidenced by the hypersensitive reaction test; $-(+)$ indicates weak and less durable EBR in a minority of cases. Experiments were carried out at least three times with similar results. 
the HR. In accordance, when a HR response was stripped of cell death and oxidative burst by $\mathrm{La}^{3+}$ treatment, there was a drop in the resistance level as well, but the extent of the residual resistance was similar to that of EBR (Ott et al. 2002). Common biochemical reactions thought to be involved in defense, like deposition of callose and phenolics in papillae, were shown to occur in response to hrp mutants and their HRinducing parent strains (Keshavarzi et al. 2004). There is a high degree of similarity between gene expression profiles induced by a HR-less nonhost pathogen (Tao et al. 2003; Z. Bozsó, unpublished data) or a PAMP (Navarro et al. 2004) and those induced early by race-specific elicitor-induced genes, whereby the possibility of stimulation of PAMP-mediated innate immune response during the HR also emerged (Navarro et al. 2004).

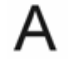

CHO1A2 /
CHO3E10/ CHO3D9 /
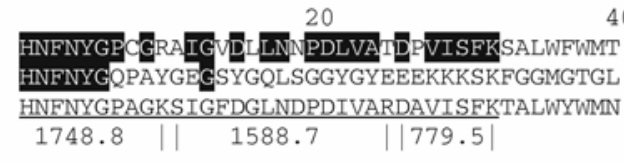

60

CHO1A2 / PQSPKPSCHDVIIGRWQPSAGDRAANRLPGFGVITNIVNG CHO3E10/ AVGAVAGVLGGVALAGGVDLLEDKIADDVAEKVEDDLADD CHO3D9 / NCHSLITSGQGFGPTIRA.INGQIECDGGNPQTVARRYEYY $1899.9 \quad \mid$

100 120

CHO1A2 / GLECGRGTDSRAQDRIGFYRRYCSILGVSPGDNLDCGNQR CHO3E10/ DGDYGGDDF

CHO3D9 / TEYCQQLGVETGDNLTC 2698.2

CHO1A2 / SFGNGLLVDTM

\section{B}

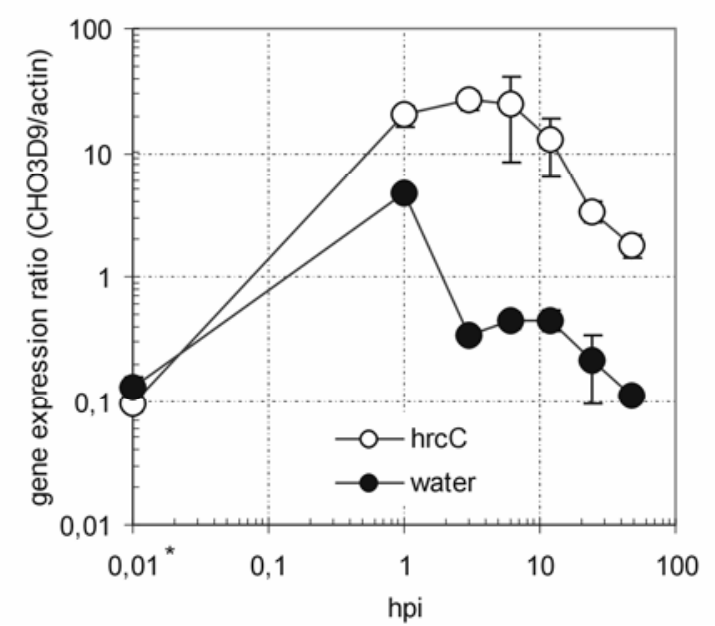

Fig. 5. Transcriptional regulation of early basal resistance (EBR)-related chitinases. A, Amino acid sequence alignment between three translated chitinase-specific polymerase chain reaction (PCR) product sequences and masses of tryptic fragments of both chitinases ('215' and '250') observed in the mass spectra. Underlined sequences in CH03D9 were confirmed by post source decay; pointed line, identified only by mass; bars mark border amino acids of peptide fragment sequences; areas with black background show partial identities between peptides and PCR products. B, Early chitinase gene induction during EBR. Transcripts corresponding to sequence $\mathrm{CHO} 3 \mathrm{D} 9$ were quantified with real-time PCR in leaf tissue infiltrated with the $P$. syringae pv. syringae hrcC mutant (EBR induced) or water (control). Ordinates show the ratio of $\mathrm{CHO} 3 \mathrm{D} 9$ and constitutive actin transcripts. The asterisk (*) indicates that first samples were actually taken immediately before inoculation. Error bars $=$ standard error of the means, $n=3$.
Virulent pathogens are normally able to create a favorable environment in their host by reprogramming its metabolism. Adaptation of $P$. syringae pv. tabaci to the host also means coping with plant defense by strategies possibly involving suppression, tolerance, and avoidance of recognition. Importantly, heat- (Burgyán and Klement 1979) or gamma ray-killed P. syringae pv. tabaci had no special characteristics as a PAMP. It did elicit EBR along with the expression of the two proteins. At unnaturally high inoculum density, even live bacteria triggered the appearance of the proteins. This observation indicates that $P$. syringae pv. tabaci does not avoid its initial recognition. Later, however, when bacteria multiply, either avoidance, tolerance, or both cannot be excluded as pathogenic strategies. For example, $P$. syringae pv. tabaci produces exopolysaccharides (Leigh and Coplin 1992) that may mask its presence, further backing the act of suppressors.

Besides, $P$. syringae pv. tabaci showed susceptibility to EBR in tandem, and even mixed, inoculation experiments. This says that EBR is a plant protection factor during pathogenesis. PAMP (flagellin) recognition has also been implicated in the basal resistance of Arabidopsis against the compatible pathogen $P$. syringae pv. tomato (Zipfel et al. 2004). It follows that $P$. syringae pv. tabaci, facing EBR, must possess a certain level of tolerance or suppressive activity. Indeed, its tolerance to EBR was found to be higher than that of the avirulent pathogens, when it was used as a challenge bacterium after an EBRinducing pretreatment (Klement et al. 2003b). Increased tolerance of a virulent bacterium to defense responses induced by its hrp mutant is well documented by the fact that the wild type as a challenge could still promote growth of the mutant used as pretreatment (Keshavarzi et al. 2004). The exopolysaccharides may contribute to tolerance to, e.g., host-derived reactive oxygen species (Kiraly et al. 1997).

EBR and EBR-related chitinase suppression by $P$. syringae pv. tabaci was evident from the absence or very low expression of the proteins during disease and from the lack of recognition avoidance discussed above. Heat treatment failed to promote the growth of the virulent bacterium (Fig. 2B), while it greatly assisted the survival of hrp mutants and late growth of the incompatible $P$. syringae pv. syringae in tobacco (Bozsó et al. 1999). Heat treatment provides here a fenocopy of the Arabidopsis nhol mutation. NHO1-mediated basal resistance (Lu et al. 2001), HR-mediated resistance, and the NHO1 glycerol kinase itself (Kang et al. 2003) were shown to be suppressed by means of an Hrp-dependent virulence mechanism of virulent bacteria. Also, $P$. syringae pv. tabaci as a pretreatment enabled $h r p$ mutants of $P$. syringae pv. syringae to retain their numbers and greatly stimulated hrp gene expression in tobacco (Klement et al. 2003b), indirectly demonstrating suppression of EBR by $P$. syringae pv. tabaci. Several PAMPinduced genes were put forward as subjects to suppression by bacterial effector proteins (Navarro et al. 2004), as were genes involved in cell-wall-based, SA-independent responses (Hauck et al. 2003) and biochemical reactions in papillae (Keshavarzi et al. 2004). The necessity and the bacterial effectors (delivered by the type III secretion system) of basal defense suppression by virulent and avirulent bacteria has recently been postulated (Alfano and Collmer 2004).

When leaves infected with $P$. syringae pv. tabaci were challenged by heat-killed $P$. syringae pv. phaseolicola, the chitinase bands appeared (Figs. 2B and 4). In similar conditions, EBR itself is suppressed (Table 1, sequence G), which means that EBR has other substantial mechanisms besides the chitinases. It also suggests that at least parts of the EBR recognition are functional during disease. Thus, a reason behind this result can be an upset balance between elicitation and suppression of the EBR-related chitinases. Accordingly, the low and 
varying amounts of the chitinases during $P$. syringae pv. tabaci infections (Figs. 2B and 4) suggest a dynamic equilibrium between the efforts of the pathogen and the plant to control the interaction. This calls for considering quantitative relationships. Indeed, EBR seems to be a quantitative (elicitor dose dependent) rather than a qualitative response. Varying levels of EBR can be measured in timecourse studies using different challenge-inoculum densities (Fig. 1A). Results with disturbed $P$. syringae pv. tabaci inocula (mixture of killed and live cells, challenge by heat-killed $P$. syringae pv. phaseolicola cells) also show that elicitation can outweigh suppression and hinder the progress of disease. Reviving early concepts (Klement 1982; Klement et al. 1978), now based on gene array data, a quantitative difference between incompatible (a high level of gene expression, high 'output intensity') and compatible (low output intensity) interactions was established. The compatible interaction was considered not robust because it was sensitive to changes of input signal intensity, which was itself intrinsically low (Tao et al. 2003). We also observed high variability-low robustness-in the expression of the EBR-related chitinases during the compatible interaction. In this context, bacterial suppressors and avoidance may decrease input signal intensity.

Our current view is that, for successful pathogenesis, suppression of or tolerance to EBR (and the related chitinases) should anticipate the inevitable EBR-elicitor potential of PAMPs that accumulate as virulent bacteria multiply.

\section{Possible functions \\ of the EBR-related extracellular chitinases.}

The EBR has rather limited bacterium-killing effect as compared with the HR (Ott et al. 2002), but its quick development seems to make amends. EBR might be sufficient against the less specialized nonpathogenic or avirulent pathogenic bacteria. Analogously to that in plant-fungal interactions (Mauch and Staehelin 1989), the possible role of chitinases in plantbacterial interactions may be multiple. Chitinases hydrolyze beta-1,4-linked sugar units on $\mathrm{N}$-acetylglucosamines, and some chitinases exhibit lysozyme (EC 3.2.1.17) activity working on a related substrate, peptidoglycan, a general component of the bacterial cell wall (Collinge et al. 1993). Plant chitinases comprise a very diverse group with respect to their physical properties (Collinge et al. 1993) and the range of potential substrates, e.g., for lysozyme activity (Brunner et al. 1998). Besides, some chitinases possess an antibacterial effect that lies in their structural properties rather than lysozyme activity (Düring et al. 1999). Extracellular chitinases may thus directly affect either metabolism, viability, or both of bacteria, microorganisms known to stay outside the cell walls of living plant cells. So the EBR-related chitinases may be plant effectors against bacterial effectors. Few indications point to this possibility in the literature. Recently Arabidopsis leaf peroxidase and exochitinase activity were shown to negatively correlate with growth of the virulent $P$. syringae pv. tomato (Traw et al. 2003). Participation in the input signal generation and amplification is again a function that is compatible with the earliness of EBR-related chitinases. Early induced chitinases with proposed similar function are known (de A Gerhardt et al. 1997). The constitutive extracellular chitinase activity seen in the present study is a particularly 'early' candidate to release elicitoractive microbial fragments from just-arrived invaders. Among plant-bacterium interactions, chitinases have a firmly established role only in nodulation, where they cleave bacterial Nod factors to control the plant response (Schultze et al. 1998). During EBR, activity of the chitinases may release further intracellular elicitors from the bacteria, leading to an enrichment of the resistance response, which might be, e.g., cold shock proteins (Felix and Boller 2003).

The EBR phenomenon is also compatible with potentiation of a response to a challenge infection by faster, improved signal transduction pathways. These activities fit within the scope of the so-called type I nonhost resistance (Mysore and Ryu 2004) that is induced by general elicitors and provides the first line of inducible, basal defense from nonself organisms.

\section{MATERIALS AND METHODS}

\section{Plant material and treatments.}

Tobacco plants (Nicotiana tabacum L. cv. Samsun) were grown in a greenhouse on commercial garden soil. For experiments two- to three-month-old plants with five to eight fully expanded leaves were used. One to two days before inoculation, the plants were placed in a growth chamber at 20 to $22^{\circ} \mathrm{C}$ with $16 \mathrm{~h}$ of light (12,000 lux intensity at plant height) and an 8-h dark period, unless indicated otherwise. Leaf interveinals were inoculated with bacterial inocula using a hypodermic syringe fitted with a 26-gauge needle (Klement 1963).

For routine detection of EBR (the HR test), bacterial at $5 \times$ $10^{8}$ cells $\mathrm{ml}^{-1}$ were used as elicitors, and this pretreated area (approximately $2 \mathrm{~cm}^{2}$ ) was challenged later with avirulent bacteria that have the potential to induce the HR in intact plants at a rate of $10^{8} \mathrm{CFU} \mathrm{ml}{ }^{-1}$. Absence or partial absence of the HR indicated that EBR has been developed. EBR was scored using a standardized scale from 1 (approximately 50\% HR) to $3(0 \%$ or fully inhibited HR). For more precise, semiquantitative assessment of EBR, three different challenge cell densities $\left(10^{7}\right.$, $10^{8}$, and $10^{9} \mathrm{CFU} \mathrm{m}{ }^{-1}$ ) were used, and their scores were averaged. For heat treatment of leaves, whole or half-leaves of plants kept at $20^{\circ} \mathrm{C}$ were immersed into a $51^{\circ} \mathrm{C}$ water bath for 15 s (Visnyovszky et al. 1983). Depending on a given plant

Table 2. Bacterial strains used in this work

\begin{tabular}{|c|c|c|c|c|}
\hline Bacterium & Designation & Relevant characteristics & Phenotype $^{\mathrm{a}}$ & Source $^{b}$ \\
\hline Escherichia coli & DH5 $\alpha$ & Not pathogenic in plants & HR - & Life Technologies, Inc. \\
\hline Pseudomonas syringae pv. coriandricola & & Pathogenic in coriander, avirulent in tobacco & $\mathrm{HR}+$ & GSPB 2784 \\
\hline P. fluorescens & & Saprophyte & $\mathrm{HR}-$ & ATCC No. 13525 \\
\hline $\begin{array}{l}\text { P. syringae pv. phaseolicola (Burkholder) } \\
\text { Young et al. }\end{array}$ & Race 6 & Pathogenic in bean, avirulent in tobacco & $\mathrm{HR}+$ & Mansfield et al. 1994 \\
\hline P. syringae pv. pisi (Sackett) Young et al. & & Pathogenic in pea, avirulent in tobacco & $\mathrm{HR}+$ & ATCC No. 11055 \\
\hline \multirow{3}{*}{$P$. syringae pv. syringae } & 61 & Weakly pathogenic in bean, avirulent in tobacco & $\mathrm{HR}+$ & Xiao et al. 1992 \\
\hline & hrpJ mutant & Hypersensitivity and pathogenicity mutant & $\mathrm{HR}-$ & Xiao et al. 1992 \\
\hline & hrc $\mathrm{C}$ mutant & Hypersensitivity and pathogenicity mutant & $\mathrm{HR}-$ & $\begin{array}{l}\text { A. Collmer, Cornell University, } \\
\text { Ithaca, NY, U.S.A. }\end{array}$ \\
\hline P. syringae pv. tabaci & $\mathrm{H} 10$ & Pathogenic, virulent in tobacco & $\mathrm{NN}+$ & NCAIM B.01601 \\
\hline
\end{tabular}

${ }^{a}$ On tobacco. $\mathrm{HR}=$ hypersensitive response and $\mathrm{NN}=$ normosensitive necrosis.

${ }^{\mathrm{b}}$ GSPB, Göttinger Sammlung Phytopathogener Bakterien (Göttingen Collection of Phytopathogenic Bacteria); ATCC, American Type Culture Collection, Manassas, Virginia, U.S.A.; NCAIM, National Collection of Agricultural \& Industrial Microorganisms, Budapest, Hungary. 
material, minor adjustments of these parameters $\left( \pm 1^{\circ} \mathrm{C}, \pm 3 \mathrm{~s}\right)$ were made, e.g., younger plants, which were less tolerant.

\section{Bacterial material and treatments.}

Bacterial strains used in this study are shown in Table 2. During the experiments Pseudomonas strains and Escherichia coli were grown on King's B media (King et al. 1954) at 26 to $28^{\circ} \mathrm{C}$. When required, media were supplemented with antibiotics kanamycin and rifampin at concentrations of 50 and $20 \mu \mathrm{g}$ $\mathrm{ml}^{-1}$, respectively. To prepare inocula, bacterial cells were washed and resuspended in distilled water at the required density, using a spectrophotometer (CO8000 cell density meter; WPA, Cambridge, U.K.). For EBR induction, late-exponential phase cells $\left(\mathrm{A}_{600}=1.6\right)$, derived from liquid culture to prepare the challenge inocula, 1-day-old cells from agar plates were used. When needed, the cells were heat-killed by putting cell suspensions into a $70^{\circ} \mathrm{C}$ water bath for $13 \mathrm{~min}$. The cell suspension was then transferred to ice and was used within an hour. Survival rate was approximately $10^{-9}$. P. syringae pv. tabaci frozen in liquid nitrogen was also killed by gamma irradiation ( 2 to $3 \mathrm{kGy}$ ) from a type $\mathrm{RH}-\gamma$ self-shielded laboratory $\mathrm{Co}_{60}$ source (Central Food Institute, Budapest). The number of viable bacteria in leaves was monitored as follows: eight leaf disks (0.9-cm diameter, excised with a cork borer) were ground with a mortar and pestle in $10 \mathrm{mM}$ potassium phosphate buffer $(\mathrm{pH} 7.0)$. Serial dilutions of the extracts were plated on King's B agar medium with or without antibiotics. Agar plates were inoculated according to an economical method (Bertoni and Mills 1987).

\section{Chemicals.}

1-Aminocyclopropane-1-carboxylic acid, SA, glycol chitin and fluorescent brightener 28 were from Sigma (St. Louis), JA from Apex Organics Ltd. (Devon, U.K.), paraquat from Imperial Chemical Industries PLC (Bracknell, England), protease inhibitor cocktails (Complete Mini) from Roche (Mannheim, Germany). Electrophoresis grade (ammonium persulfate, Bromphenol Blue, sodium acetate, glycerol, glycine) chemicals were from Sigma and others from Reanal (Budapest, Hungary).

\section{Sampling for electrophoresis.}

For critical comparisons, opposite halves of the same leaves or leaves of the same developmental stage with a similar intercellular space/cell surface ratio were used. Preparation of IWF was based on the method of Klement (1965) and its modification (Rohringer et al. 1983). Tobacco leaf panels were cut out, were washed briefly under tap water and then distilled water, and were vacuum-infiltrated with distilled water. IWF was obtained by centrifuging plastic strip-supported leaf rolls with $500 \times g$ force parallel to the leaf plane in a swinging rotor for $15 \mathrm{~min}$ at $4^{\circ} \mathrm{C}$. IWF was centrifuged $(22,000 \times g, 15 \mathrm{~min}$ at $4^{\circ} \mathrm{C}$ to remove insoluble material and bacterial cells) and was stored at $-70^{\circ} \mathrm{C}$. Smaller samples of 50 to $150 \mu \mathrm{l}$ could be obtained with a novel method that was developed for a fixed angle rotor. Here, one or two interveinal areas of vacuum-infiltrated leaves were placed in a standard $25-\mathrm{mm}$ diameter plastic centrifuge tube onto the side distant from the rotor axis. Protease inhibitors were used only during preparation of proteins for mass spectrometry but not for routine detection.

\section{Electrophoresis.}

Discontinuous acrylamide gradient (10 to $20 \%$ for small gels, Bio-Rad mini protean 3 system [Bio-Rad, Hercules, CA, U.S.A.] and 3 to $20 \%$ for large gels (Hoefer SE600 system Hoefer, San Francisco) native gels were prepared according to the Ornstein-Davis buffer system ( $\mathrm{pH} 6.8$ for stacking gels, $\mathrm{pH}$ 8.8 for resolving gels, and $\mathrm{pH} 8.3$ for running buffer).
A $25-\mu$ aliquot of IWF was used with bromophenol blue indicator. Its protein level ( 1 to $2 \mu \mathrm{g}$ ) was not adjusted to allow comparisons between individual bands. Large gels were run at constant $15 \mathrm{~mA}$ current at $4^{\circ} \mathrm{C}$ for 6 to $8 \mathrm{~h}$, small gels at constant voltages, first at $110 \mathrm{~V}$ for $20 \mathrm{~min}$ and then at $160 \mathrm{~V}$ for $100 \mathrm{~min}$. The gels were stained with silver (Tschernuschko 1996), were photographed, and were subjected to densitometry using an Alphainnotech TM-26 imager.

In-gel chitinase activity assay of IWF was conducted by analyzing band intensity using ultraviolet transillumination in an overlay gel containing $0.04 \%$ glycol chitin and a fluorescence enhancer, fluorescent brightener 28 (Trudel and Asselin 1989).

\section{Mass spectrometry.}

IWF from plants treated with heat-killed $P$. syringae pv. phaseolicola cells was collected at 12 to 19 hpi and concentrated about 40 -fold by ultrafiltration with a $5-\mathrm{kDa}$ cut-off regenerated cellulose filter (Millipore, Bedford, MA, U.S.A.). Protease inhibitors were used for concentration of the two proteins, but the number of filtration steps should be kept to a minimum, as the proteins tended to bind to the filter membranes. Concentrated (about 40-fold) samples were subjected to electrophoresis on large gels. Gels were stained with Coomassie brilliant blue, and gel pieces containing distinct protein bands were cut out. Coomassie brilliant blue and salts were removed using a $1: 150-\mathrm{mM} \mathrm{NH}_{4} \mathrm{HCO}_{3}$ /acetonitrile solution. The disulfide-bridges were reduced with dithiothreitol, alkylated with iodoacetamide. The protein was in-gel digested with Promega (Madison, WI. U.S.A.) side chain-protected porcine trypsin. The resulting peptides were extracted with a 1:1 $\mathrm{H}_{2} \mathrm{O}$ /acetonitrile mixture containing $5 \%$ trifluoroacetic acid. Mass spectrometry analyses of peptides were performed on a Bruker Reflex III matrix-assisted laser desorption-ionization time of flight (MALDI-TOF) mass spectrometer (Bruker Daltonic, Leipzig, Germany). The tryptic digest was purified on a C18 Zip-tip (Millipore) and was analyzed unfractionated by MALDI-TOF MS using 2,5-dihydroxy-benzoic acid as the matrix. Trypsin autolysis products $\mathrm{m} / \mathrm{z} 842.51$ and 2211.1 served as standards for internal calibration (Protein Prospector software, Clauser et al. 1999). PSD analysis was performed on selected components in 10 to 12 steps, lowering the reflectron voltage by $25 \%$ at each step, and the data was eventually stitched together. While the MS conditions permitted monoisotopic mass measurements, in PSD mode, average masses were determined.

\section{RNA extraction and cDNA construction.}

Total RNA was extracted using the plant total RNA extraction miniprep system (Viogene Biotek, Taipei, Taiwan) as suggested by the manufacturer. Approximately $0.1 \mathrm{~g}$ of leaf tissue was ground in liquid nitrogen 1 to $48 \mathrm{hpi}$. RNA content was assayed by UV spectrophotometry at $260 \mathrm{~nm}$.

Reverse transcription of $2.5 \mu \mathrm{g}$ of total RNA was carried out using RevertAid $\mathrm{H}$ minus first strand cDNA synthesis kit (Fermentas, Vilnius, Lithuania), using the TP primer (TP: 5' GAC TCG AGT CGA CAT CGA(T) $)_{17}$; Frohman 1990) in the case of 3'Race PCR or the oligo(dT) primer from the kit in the case of real-time PCR according to the manufacturer's instructions.

\section{3'Race cloning of homologous sequences.}

A cDNA pool containing fragments of EBR-related genes was constructed from tobacco leaves treated with the $P$. syringae pv. syringae hrcC mutant. Redundant gene-specific PCR primer was designed on the conserved region of the chitinase peptides. Conserved regions (HNFNYG) were sought using known tobacco and Arabidopsis chitinase sequences. The re- 
sulting primer was $\mathrm{CHTO}$, 5' CAC AAC T(A/T)(C/T) AAC $\mathrm{TA}(\mathrm{C} / \mathrm{T}) \mathrm{GG}(\mathrm{A} / \mathrm{G}) \mathrm{C} 3^{\prime}$. The $3^{\prime}$ end of the cDNA fragment was obtained by the EP primer (5' GAC TCG AGT CGA CAT CG3') on the TP adaptor region (Frohman 1990). cDNA from an EBR time series was PCR-amplified using the above pair of primers at $94^{\circ} \mathrm{C}$ for $2 \mathrm{~min}, 94^{\circ} \mathrm{C}$ for $45 \mathrm{~s}, 55^{\circ} \mathrm{C}$ for $1 \mathrm{~min}$, $72^{\circ} \mathrm{C}$ for $1 \mathrm{~min} 35 \times$ to step 2 , and finally $72^{\circ} \mathrm{C}$ for $10 \mathrm{~min}$. Total volume was $25 \mu \mathrm{l}$, comprising $2.5 \mu \mathrm{l}$ of cDNA sample, 100 pmol of each primer, $200 \mu \mathrm{M}$ dNTPs (Fermentas), and 2.5 units of Taq DNA polymerase LC (recombinant) in the provided buffer (Fermentas). Samples were run on a $2 \%$ agarose gel, were visualized by ethidium bromide. Bands were excised by a scalpel and gel-eluted by gel-extraction miniprep kit (Viogene). Fragments were cloned by Promega's pGEM-T Vector System-I.

Sequencing of clones was carried out using plasmid DNA at the sequencing facility of MWG-Biotech AG (Ebersberg, Germany). Vector and adaptor sequences were removed manually. Clone identification was performed using BLAST search (Altschul et. al. 1990).

\section{Quantitative RT-PCR analysis of gene expression.}

Upper and lower primer sequences for the three clones described in the text were as follows:

\section{CHO1A2: 5' TGG ATT TGG CGT CAT CA 3'; 5' TCC CTT CAG GTC ACA ATC A 3';

We used $2.5 \mu$ of a 10-fold dilution of the cDNA stock (prepared as described above) in 15- $\mu$ l reactions. Primer concentrations were $3 \mu \mathrm{M}$. PCR was carried out using the iQ SYBR green $2 \times$ supermix (Bio-Rad) on the DNA Engine Opticon 2 (MJ Research [Bio-Rad Laboratories], Waltham, MA, U.S.A.). Cycling parameters were as follows: initial $95^{\circ} \mathrm{C}$ for $6 \mathrm{~min}$, followed by 40 cycles of $95^{\circ} \mathrm{C}$ for $30 \mathrm{~s}$, annealing for $1 \mathrm{~min}$, and $72^{\circ} \mathrm{C} 40 \mathrm{~s}$, plate-read step. Annealing temperatures for $\mathrm{CHO} 1 \mathrm{~A} 2$, $\mathrm{CHO} 3 \mathrm{D} 9$, and $\mathrm{CHO} 3 \mathrm{E} 10$ were 55,52 , and $60^{\circ} \mathrm{C}$, respectively. Measured cycle threshold values were always normalized against actin (internal control) values. Every sample was measured at least twice and standard deviations were calculated. Values of the noninoculated controls were given the arbitrary value of 1 ; other sample values are relative to the controls.

\section{ACKNOWLEDGMENTS}

This work was supported by the Hungarian Scientific Research Fund (Országos Tudományos Kutatási Alap, OTKA) Nos. T038302, Ts040835, T037916 and F037700). We are indebted to K. Rudolph and G. Wolf, Institut für Pflanzenpathologie und Pflanzenschutz der Georg-August-Universität, Göttingen, Germany, for their encouragement and advice during pilot studies. We are also grateful to the Microbiology Department, Central Food Institute, Budapest, Hungary, for providing the gamma radiation source.

\section{LITERATURE CITED}

Alfano, J. R., and Collmer, A. 2004. Type III secretion system effector proteins: Double agents in bacterial disease and plant defense. Annu. Rev. Phytopathol. 42:385-414.

Altschul, S. F., Gish W., Miller, W., Myers, E. W., and Lipman D. J. 1990. Basic local alignment search tool. J. Mol. Biol. 215:403-410.

Alvarez, M. E. 2000. Salicylic acid in the machinery of hypersensitive cell death and disease resistance. Plant Mol. Biol. 44:429-442.

Andi, S., Taguchi, F., Toyoda, K., Shiraishi, T., and Ichinose, Y. 2001. Effect of methyl jasmonate on harpin-induced hypersensitive cell death, generation of hydrogen peroxide and expression of PAL mRNA in tobacco suspension cultured BY-2 cells. Plant Cell Physiol. 42:446-449.

Asai, T., Tena, G., Plotnikova, J., Willmann, M. R., Chiu, W. L., GomezGomez, L., Boller, T., Ausubel, F. M., and Sheen, J. 2002. MAP kinase signaling cascade in Arabidopsis innate immunity. Nature 415:977-983.

Bertoni, G., and Mills, D. 1987. A simple method to monitor growth of bacterial populations in leaf tissue. Phytopathology 77:832-835.

Bozsó, Z., Ott, P. G., Kecskés, M. L., and Klement, Z. 1999. Effect of heat and cycloheximide treatment of tobacco on the ability of Pseudomonas syringae pv. syringae $61 \mathrm{hrp} / \mathrm{hrmA}$ mutants to cause HR. Physiol. Mol. Plant Pathol. 55:215-223.

Brunner, F., Stintzi, A., Fritig, B., and Legrand, M. 1998. Substrate specificities of tobacco chitinases. Plant J. 14:225-234.

Burgyán, J., and Klement, Z. 1979. Early induced selective inhibition of incompatible bacteria in tobacco plants. Phytopathol. Mediterr. 18:153161.

Clauser, K. R., Baker, P. R., and Burlingame, A. L. 1999. Role of accurate mass measurement $( \pm 10 \mathrm{ppm})$ in protein identification strategies employing MS or MS/MS and database searching. Anal. Chem. 71:28712882

Collinge, D.B., Kragh, K.M., Mikkelsen, J.D., Nielsen, K.K., Rasmussen, U., and Vad, K. 1993. Plant chitinases. Plant J. 3:31-40.

de A Gerhardt, L. B., Sachetto-Martins, G., Contarini, M. G., Sandroni, M., de P. Ferreira, R., de Lima, V. M., Cordeiro, M. C., de Oliveira, D. E., and Margis-Pinheiro, M. 1997. Arabidopsis thaliana class IV chitinase is early induced during the interaction with Xanthomonas campestris. FEBS (Fed. Eur. Biochem. Soc.) Lett. 419:69-75.

Düring, K., Porsch, P., Mahn, A., Brinkmann, O., and Gieffers, W. 1999. The non-enzymatic microbicidal activity of lysozymes. FEBS (Fed. Eur. Biochem. Soc.) Lett. 449:93-100.

Felix, G., and Boller, T. 2003. Molecular sensing of bacteria in plants. The highly conserved RNA-binding motif RNP-1 of bacterial cold shock proteins is recognized as an elicitor signal in tobacco. J. Biol. Chem. 278:6201-6208.

Felix, G., Duran, J. D., Volko, S., and Boller, T. 1999. Plants have a sensitive perception system for the most conserved domain of bacterial flagellin. Plant J. 18:265-276.

Frohman, M. A. 1990. RACE: Rapid amplification of cDNA ends. In: PCR Protocols: A Guide to Methods and Applications. M. A. Innis, D. H. Gelfand, J. J. Sninsky, and T. J. White, eds. Academic Press, New York.

Graham, T. L., Sequeira, L., and Huang, T. S. 1977. Bacterial lipopolysaccharides as inducers of disease resistance in tobacco. Appl. Environ. Microbiol. 34:424-432.

Hauck, P., Thilmony, R., and He, S. Y. 2003. A Pseudomonas syringae type III effector suppresses cell wall-based extracellular defense in susceptible Arabidopsis plants. Proc. Natl. Acad. Sci. U.S.A. 100:85778582 .

Jones, D. A., and Takemoto, D. 2004. Plant innate immunity-Direct and indirect recognition of general and specific pathogen-associated molecules. Curr. Opin. Immunol. 16:48-62.

Kang, L., Li, J., Zhao, T., Xiao, F., Tang, X., Thilmony, R., He, S., and Zhou, J. M. 2003. Interplay of the Arabidopsis nonhost resistance gene NHO1 with bacterial virulence. Proc. Natl. Acad. Sci. U.S.A. 100:35193524

Kecskés, M. L,, Ahohuendo, B., Müller, P., Schröder, I., Rudolph, K., Bozsó, Z., Ott, P. G., and Klement, Z. 1999. Some details about the involvement of lipopolysaccharides in resistance induction against phytopathogenic bacteria. (19. Arbeitskreis für Phytobakteriologie, Jena, Germany) Phytomedizin, Mitteilungen der Deutschen Phytomedizinischen Gesellschaft. 29:43-44.

Keshavarzi, M., Soylu, S., Brown, I., Bonas, U., Nicole, M., Rossiter, J., and Mansfield, J. 2004. Basal defenses induced in pepper by lipopolysaccharides are suppressed by Xanthomonas campestris pv. vesicatoria. Mol. Plant-Microbe Interact. 17:805-815.

King, E. D., Ward, M. K., and Raney, D. E. 1954. Two simple media for the demonstration of pyocyanin and fluorescein. J. Lab. Clin. Med. 44:301-307.

Kiraly, Z., Elzahaby, H. M., and Klement, Z. 1997. Role of extracellular polysaccharide (EPS) slime of plant pathogenic bacteria in protecting cells to reactive oxygen species. J. Phytopathol. 145:59-68.

Klement, Z. 1963. Method for the rapid detection of the pathogenicity of phytopathogenic Pseudomonas. Nature 199:299-300.

Klement, Z. 1965. Method of obtaining fluid from the intercellular spaces of foliage and the fluids merit as substrate for phytobacterial pathogens. Phytopathology 55:1033-1034.

Klement, Z. 1982. Hypersensitivity. Pages 149-177 in: Phytopathogenic Prokaryotes. M. S. Mount, and G. H, Lacy, eds. Academic Press, New York.

Klement, Z., Farkas, G., and Lovrekovich, L. 1964. Hypersensitive reaction induced by phytopathogenic bacteria in the tobacco leaf. Phytopathology 54:474-477.

Klement, Z., Hevesi, M., and Sasser, M. 1978. Mechanism of the development of wildfire disease in susceptible tobacco plant. Pages 679-685 in: 
Proceedings of the 4th International Conference Plant Pathogenic Bacteria, Angers, France.

Klement, Z., Bozsó, Z., Ott, P.G., Kecskés, M. L., and Rudolph, K. 1999. Symptomless resistant response instead of the hypersensitve reaction in tobacco leaves after infiltration of heterologous pathovars of Pseudomonas syringae. Phytopath. Z. 147:467-475.

Klement, Z., Bozsó, Z., Besenyei, E., Czelleng, A., and Ott, P. G. 2003a. Early induced resistance (EIR) is a general, symptomless plant response to bacteria. Pages 301-309 in: Pseudomonas syringae and related pathogens. N. S. Iacobellis, A. Collmer, S. W. Hutcheson, J. W. Mansfield, C. E. Morris, J. Murillo, N. W. Schaad, D. E. Stead, G. Surico, and M. S. llrich, eds. Kluwer Academic Publishers, Dordrecht, The Netherlands.

Klement, Z., Bozsó, Z., Kecskés, M. L., Besenyei, E., Arnold, C., and Ott, P. G. 2003b. Local early induced resistance of plants as the first line of defence against bacteria. Pest Manag. Sci. 59:465-474.

Kunkel, B. N., and Brooks, D. M. 2002. Cross talk between signaling pathways in pathogen defense. Curr. Opin. Plant Biol. 5:325-331.

Leigh, J. A., and Coplin, D. L. 1992. Exopolysaccharides in plant-bacterial interactions. Annu. Rev. Microbiol. 46:307-346.

Lovrekovich, L., and Farkas, G. L. 1965. Induced protection against wildfire disease in tobacco leaves treated with heat-killed bacteria. Nature 205:823-824.

Lozano, J. C., and Sequeira, L. 1970. Prevention of the hypersensitive reaction in tobacco leaves by heat-killed bacterial cells. Phytopathology 60:875-879.

Lu, M., Tang, X., Zhou and J. M. 2001. Arabidopsis NHO1 is required for general resistance against Pseudomonas bacteria. Plant Cell 13:437447.

Mansfield, J., Jenner, C., Hockenhull, R., Bennett, M. A., and Stewart, R. 1994. Characterization of avrPphE, a gene for cultivar- specific avirulence from Pseudomonas syringae pv. phaseolicola which is physically linked to $h r p Y$, a new $h r p$ gene identified in the halo-blight bacterium. Mol. Plant-Microbe Interact. 7:726-739.

Mauch, F., and Staehelin, L. A. 1989. Functional implications of the subcellular localization of ethylene-induced chitinase and beta-1,3-glucanase in bean leaves. Plant Cell 1:447-457.

Mazzucchi, U., Bazzi, C., and Pupillo, P. 1979. The inhibition of susceptible and hypersensitive reactions by protein-lipopolysaccharide complexes from phytopathogenic pseudomonads. Physiol. Mol. Plant Pathol. 14:19-30.

Mittler, R. 2002. Oxidative stress, antioxidants and stress tolerance. Trends Plant Sci. 7:405-410.

Mysore, K. S., and Ryu, C. M. 2004. Nonhost resistance: How much do we know? Trends Plant Sci. 9:97-104.

Navarro, L., Zipfel, C., Rowland, O., Keller, I., Robatzek, S., Boller, T., and Jones, J. D. 2004. The transcriptional innate immune response to flg22. Interplay and overlap with Avr gene-dependent defense responses and bacterial pathogenesis. Plant Physiol. 135:1113-1128.

Newman, M. A., Daniels, M. J., and Dow, J. M. 1997. The activity of lipid A and core components of bacterial lipopolysaccharides in the prevention of the hypersensitive response in pepper. Mol. Plant-Microbe Interact. 10:926-928.

Nurnberger, T., and Brunner, F. 2002. Innate immunity in plants and animals: Emerging parallels between the recognition of general elicitors and pathogen-associated molecular patterns. Curr. Opin. Plant Biol. 5:318-324.

Ohashi, Y., and Ohshima, M. 1992. Stress-induced expression of genes for pathogenesis-related proteins in plants,. Plant Cell Physiol. 33:819-826.

Ott, P. G., Klement, Z., Nagy, I., and Ádám, A. L. 2003. Lanthanum inhibits programed cell death but not resistance in the tobacco-Pseudomonas savastanoi pv. phaseolicola incompatible interaction. Pages 335-344 in: Pseudomonas syringae and related pathogens. N. S. Iacobellis, A. Collmer, S. W. Hutcheson, J. W. Mansfield, C. E. Morris, J. Murillo, N. W. Schaad, D. E. Stead, G. Surico, and M. S. Ullrich, eds. Kluwer Academic Publishers, Dordrecht, The Netherlands.

Rao, M. V., Lee, H., Creelman, R. A., Mullet, J. E., and Davis, K. R. 2000. Jasmonic acid signaling modulates ozone-induced hypersensitive cell death. Plant Cell 12:1633-1646.

Rohringer, R., Ebrahim-Nesbat, F., and Wolf, G. 1983. Proteins in intercellular washing fluids from leaves of barley (Hordeum vulgare L.). J. Exp. Bot. 34:1589-1605.

Schultze, M., Staehelin, C., Brunner, F., Genetet, I., Legrand, M., Fritig, B., Kondorosi, E., and Kondorosi, A. 1998. Plant chitinase/lysozyme isoforms show distinct substrate specificity and cleavage site preference towards lipochitooligosaccharide Nod signals. Plant J. 16:571-580.

Schulze-Lefert, P. 2004. Plant immunity: The origami of receptor activation. Curr. Biol. 14:R22-R24.

Sequeira, L., Aist, S., and Ainslie, V. 1972. Prevention of the hypersensitive reaction on tobacco by proteinaceous constituents of Pseudomonas solanacearum. Phytopathology 62:536-541.

Stefani, E., Bazzi, C., and Mazzucchi, U. 1994. Modification of the Pseudomonas syringae pv. tabaci- tobacco leaf interaction by bacterial oligosaccharides. Physiol. Mol. Plant Pathol. 45:397-406.

Steiner, U., and Schönbeck, F. 1995. Induced disease resistance in monocots. Pages 86-110 in: Induced Resistance to Disease in Plants. R. Hammerschmidt, and J. Kuc, eds. Kluwer Academic Publishers, Dordrecht, The Netherlands.

Tao, Y., Xie, Z. Y., Chen, W. Q., Glazebrook, J., Chang, H. S., Han, B. Zhu, T., Zou, G. Z., and Katagiri, F. 2003. Quantitative nature of Arabidopsis responses during compatible and incompatible interactions with the bacterial pathogen Pseudomonas syringae. Plant Cell 15:317-330.

Traw, M. B., Kim, J., Enright, S., Cipollini, D. F., and Bergelson, J. 2003. Negative cross-talk between salicylate- and jasmonate-mediated pathways in the Wassilewskija ecotype of Arabidopsis thaliana. Mol. Ecol. 12:1125-1135.

Trudel, J., and Asselin, A. 1989. Detection of chitinase activity after polyacrylamide gel electrophoresis. Anal. Biochem. 178:362-366.

Tschernuschko, R. 1996. PhD Thesis, Georg-August-Universität, Göttingen, Germany.

Visnyovszky, E., Hevesi, M., and Klement, Z. 1983. Early and late induced resistance of plants against bacteria. Tag. -Ber. Akad. Landwirtsch. Wiss. DDR Berlin 216:357-364.

Welch, W. J., and Suhan, J. P. 1985. Morphological study of the mammalian stress response: Characterization of changes in cytoplasmic organelles, cytoskeleton, and nucleoli, and appearance of intranuclear actin filaments in rat fibroblasts after heat-shock treatment. J. Cell Biol. 101:1198-1211.

Xiao, Y., Lu, Y., Heu, S., and Hutcheson, S. W. 1992. Organization and environmental regulation of the Pseudomonas syringae pv. syringae 61 hrp cluster. J. Bacteriol. 174:1734-1741.

Yost, H. J., and Lindquist, S. 1986. RNA splicing is interrupted by heat shock and is rescued by heat shock protein synthesis. Cell 45:185-193.

Zipfel, C., Robatzek, S., Navarro, L., Oakeley, E. J., Jones, J. D., Felix, G., and Boller, T. 2004. Bacterial disease resistance in Arabidopsis through flagellin perception. Nature 428:764-767.

\section{AUTHOR-RECOMMENDED INTERNET RESOURCE}

University of California, San Francisco's Protein Prospector webpage: prospector.ucsf.edu 